\title{
MODEL KEBIJAKAN PENGELOLAAN SAMPAH DAERAH DALAM MEWUJUDKAN MASYARAKAT SEJAHTERA
}

\author{
Nining latianingsih ${ }^{1)}$, dewi winarni susyanti ${ }^{2)}$ dan iis Mariam $^{3)}$ \\ 1,2,3 Jurusan Administrasi Niaga Politeknik Negeri Jakarta \\ Email : ${ }^{1}$ nining.latianingsih@bisnis.pnj.ac.id
}

\begin{abstract}
One of the greatest challenges experienced by developing countries is the emergence of environmental problems that can not be separated from economic development. This can be illustrated in the relationship between the increase in population and the increasing tarap of community life on the one hand can support economic growth and on the other hand can also lead to a decline in development The problem of waste management is one aspect of development that is very important and requires the involvement between government, business / private, colleges and the general public. While the formulation of the problem of how the policy and the concept of waste management in urban areas, How to solve the problem of waste in the community in the city of Depok, What obstacles that cause the management and processing of waste in the city of Depok has not run well. The method that will be used in this research is using qualitative descriptive research method and passed by through stages, that is mapping of local waste treatment policy, evaluating the processing of garbage area. One of the goals of local government is to minimize waste. While the targets achieved from this research is the model of waste management dilaksaakan by local government of Depok city can realize a clean life, environmentally friendly and organized waste processing and improve the economy of society. The resulting model of research, in order to be implemented in accordance with the mandate of the respective regional regulations and impact on waste reduction and economic improvement of the community.
\end{abstract}

Keywords: local policy, waste processing, economic improvement of society, domestic waste pollution, evaluation of local waste.

\begin{abstract}
Abstrak
Salah satu tantangan terberat yang dialami oleh negara berkembang adalah timbulnya permasalahan lingkungan yang tidak bisa terlepas dari pembangunan ekonomi. Hal ini dapat diilustrasikan dalam hubungan antara kenaikan jumlah penduduk dan meningkatnya tarap hidup masyarakat yang disatu sisi dapat menunjang pertumbuhan ekonomi dan di sisi lain juga dapat menimbulkan penurunan pembangunan Masalah pengelolaan sampah merupakan salah satu aspek dalam pembangunan yang sangat penting dan memerlukan keterlibatan antara pemerintah, bisnis/swasta, perguruan tinggi dan masyarakat umum. Sedangkan perumusan masalah bagaimana kebijakan serta konsep pengelolaan sampah di perkotaan, Bagaimana mengatasi masalah sampah pada masyarakat di kabupaten Bogor, Hambatan apa yang menyebabkan pengelolaan serta pengolahan sampah di kabupaten Bogor belum berjalan dengan baik. Metode yang akan dipakai dalam pencapai penelitian ini adalah menggunakan metode penelitian deskriptif kualitattif dan dilalui dengan melalui tahapan-tahapan, yaitu mapping kebijakan pengolahan sampah daerah, mengevaluasi pengolahan sampah daerah. Salah satu tujuan dari pemerintah daerah adalah untuk meminimalisir sampah. Sedangkan target yang dicapai dari penelitian ini adalah model pengelolaan sampah yang dilaksaakan oleh pemerintah daerah kabupaten Bogor, dapat mewujudkan kehidupan sejahtera, bersih, ramah lingkungan serta tertata pengolahan sampahnya dan meningkatkan ekonomi masyarakat. Model yang dihasilkan dari penelitian, agar dapat diterapkan sesuai dengan amanat dari peraturan daerah masing-masing dan berdampak pada pengurangan sampah dan peningkatan ekonomi masyarakat.
\end{abstract}

Kata kunci: kebijakan daerah, Pengolahan sampah, peningkatan ekonomi masyarakat, pencemaran limbah domestik, evaluasi sampah daerah 


\section{PENDAHULUAN}

Undang-Undang No 18 tahun 2008 tentang pengolahan sampah belum tersosialisasi dengan baik. Hal ini dapat diamati dari lingkungan di sekitar kantorkantor Pemerintah maupun Rumah Sakit. Kampus bahkan tempat sekolah, yang belum mencerminkan pesan dari UU tersebut. Persoalan ini muncul disebabkan oleh terbatasnya kapasitas pelayanan yang dimiliki pemerintah daerah atau pemerintah kota setempat, sedangkan laju produksi sampah terus meningkat secara eksponensial.

Sampah adalah salah satu penyumbang gas rumah kaca dalam bentuk $\mathrm{CH} 4$ dan CO2 (karbondioksida). Pembuangan sampah terbuka (open dumping) di tempat pembuangan akhir (TPA) sampah mengakibatkan sampah organik yang tertimbun mengalami dekomposisi. Proses dekomposisi itu menghasilkan gas CH4 (methane). Sampah yang dibakar juga akan menghasilkan karbondioksida. Gas methane mempunyai kekuatan merusak 20 kali lipat dari gas karbondioksida. Dengan keadaan ini generasi manusia selanjutnya tidak akan pernah melihat air mengalir dari kran karena habisnya mata air pegunungan. Begitu pula tanah menjadi tandus tanpa pepohonan. Sumber daya alam yang sekarang kita pikir murah dan gratis akan menjadi barang langka dan mahal. Seperti yang sudah dilaksakana melalui penelitian awal, antara lain melalui jalur daur ulang yang masih perlu disosialisasikan. Sampah daur ulang dikumpulkan dari sumbernya, seperti perumahan, kawasan komersial, tempat penampungan sementara (TPS) dan TPA. Permasalahan dalam penelitian ini adalah Bagaimana pengelolaan dan pengolahan sampah daerah dihubungkan dengan kebijakan sampah daerah?

\section{METODE PENELITIAN}

Metode penelitian disini menggunakan metode deskriptif yang menggambarkan detail khusus dari suatu keadaan, situasi social atau hubungan sosial (Newman 1977 : 239). Penelitian ini menggambarkan kegiatan yang dilakukan pada objek tertentu secara jelas dan sistematis.(Sukardi. 2003:14). Jika dilihat dari aspek tujuan, penelitian ini termasuk penelitian terapan karena penelitian terapan menggambarkan permasalahan yang terjadi dan memecahkannya dan hasil penelitian dapat dimanfaatkan untuk kepentingan manusia baik secara individual maupun kelompok, oleh karena itu, pada penelitian ini penulis mencoba untuk menggambarkan pengelolaan sampah daerah dan menghubungkanna dengan kebijakan pengelolaan sampah daerah di kota Depok. Dengan pendektan penelitian terapan, diharapkan adanya pemecahan permasalah yang terindentifikasi sehingga hasilnya dapat dimanfaatkan untuk kepentingan pembangunan nasional.

Subyek dari penelitian ini adalah pengelola sampah daerah, yang dalam hal ini dinas Kebesihan daerah, masyarakat pengelola sampah secara mandiri, selain pengelola yang menjadi subyek dari penelitian ini adalah pembuat kebijakan pengelolaan sampah daerah.

Objek dari penelitian adalah kebijakan pengelolaan sampah daerah, yang meliputi prinsip-prinsip pengelolaan sampah daerah yaitu system informasi, prinisp pengelolaan pelayanan, prinsip pengelolaan pegnembangan, prinsip pengelolaan produksi untuk meningkatkan efektifitas dan efiseiansi pengelolaan sampah daerah serta faktorfaktor pendukung dan factor-faktor penghambat keberhailan pengelolaan sampah daerah di kota Depok.

Penelitian ini menggunakan teknik pengumpulan data yaitu melalui penelitian dokumentasi dan penelitian lapangan. Penelitian dokumentasi atau studi literature dilakukan untuk mencari sumber-sumber tertulis yang dapat dijadikan landasan teori guna memperkuat analysis data dalam penelitian ini. literature yang dicari dan digunakan 
dalam penelitian ini adalah dokumendiokumen yang membahas tentang kebijakan pengelolaan sampah daerah termasuk kebijakan pengelolaan sampah di Pusat. Penelitian lapangan dimaksudkan untuk mendapatkan datadata secara langsung dari objek penelitian yaitu melalui wawancara dan obersevasi.

Teknik dokumentasi dipilih oleh penulis karena teknik ini dapat memperoleh informasi dari bermacam-macam sumber tertulis atau dokumen yang dimiliki oleh pemerintah daerah kabupaten/kota. Data ini adalah data dokumen yang berhubungan dengan pengelolaan sampah seperti data peraturan daerah, peraturan bupati atau walikota yang berhubungan dengan pengelolaan samapah.

Teknik wawancara adalah usaha mengumpulkan informasi dengan mengajukan pertanyaan secara lisan oleh informan. Teknik wawancara yang digunakan adalah teknik wawancara tersturuktur dimana penelitian ketika melakukan tatap muka dengan responden menggunakan pedoman wawancara yang telah disiapkan terlebih dahulu. Wawancara akan dilakukan kepada:

1) Kepala dinas kebersihan atau kepala bagian yang mengelolaa sampah daerah di Kota Depok

2) Masyarakat langung ke pengelola sampah mandiri sesuai dengan kebijakan pada daerah masingmasing.

3) Masyarakat umum yang ada didaerah masing-masing yang terpilih.

Setelah pengumpulan data selesai, tahap selanjutnya adalah pengolahan data dan analsis data. Analisis data kualitatif adalah upaya yang dilakukan dengan jalan bekerja dengan data, mengorganisasikan data, memilah-milah data menjadi satuan yang dapat dikelola, mensistesiskan, mencari dan menemukan pola, menemukan apa yang penting dan apa yang bisa di pelajarai, dan memutuskan apa yang dapat diceritakan kepada orang lini. Analisa data pada penelitian kualitatif yaitu dengan menginterpretasikan hasil penelitian yang diperoleh di tempat penelitian di Kota Depok.

\section{HASIL DAN PEMBAHASAN}

Potensi Pengelolaan Sampah Menuju Zero Waste. Sebaiknya melalui Pengelolaan sampah baik di perkotaan maupun didaerah adalah mulai dari produksi sampai berakhirnya suatu proses produksi dapat dihindari terjadi produksi sampah atau diminimalisir terjadinya sampah .Urip Santoso, 2009. Konsep Zero Waste ini salah satunya dengan menerapkan prinsip $3 \mathrm{R}$ (Reduce, Reuse, Recycle). Pemikiran konsep zero waste adalah pendekatan serta penerapan sistem dan teknologi pengolahan sampah perkotaan skala individual dan skala kawasan secara terpadu dengan sasaran untuk dapat mengurangi volume sampah sesedikit mungkin. Konsep 3R adalah merupakan dasar dari berba-gai usaha untuk mengurangi limbah sampah dan mengoptimalkan proses produksi sampah .Suryanto dkk., 2005. Oleh karena itu perlu diselaraskan dengan pengelolaan Sampah Berbasis Masyarakat (Community Based Solid Waste Management/CBSWM) adalah suatu pendekatan pengelolaan sampah yang didasarkan pada kebutuhan dan permintaan masyarakat, direncanakan, dilaksanakan, dikontrol, dan di evaluasi bersama masyarakat (Environmental Services Program (ESP) DKI, 2006).

Pengorganisasian tentang pemberdayaan masyarakat dan stakeholder khususnya dalam pengelolaan dan pengolah sampah daerah berdasarkan kebijakan pada masing- masing kabupten kota, menjadi fasilitator terhadap kegiatan di tingkat komunitas/masyarakat di kawasan lokasi terpilih. Tahap ini dibagi menjadi 4 kegiatan: melakukan identifikasi lokasi terpilih, melakukan sosialisasi pada masyarakat dengan cara memperkenalkan program pengelolaan sampah, pembentukan organisasi, 
melakukan pelatihan pengelolaan sampah terpadu. pengelolaan sampah sudah dilakukan oleh beberap peneliti seberlumnya, antara lain, Bambang Munas Dwiyanto, dengan judul penelitian Model Peningkatan Partisipasi Masyarakat dan Penguatan Sinergi dalam Pengelolaan Sampah Perkotaan, termuat dalam jurnal jurnal Ekonomi Pembangunan Volume 12, Nomor 2, Desember 2011: 239-256. Dengan hasil penelitiannya menyebutkan bahwa Sistem pengelolaan sampah di Kota Semarang dapat dikatakan masih tergolong menggunakan konsep tradisional yang menganut konsep kumpul, angkut, dan buang. Sistem ini masih terus digunakan karena masyarakat belum mengetahui cara pengelolaan sampah dengan baik.

Tujuan khusus dan manfaat penelitian yang dicapai dari penelitian ini adalah:

1. Menghasilkan Model Kebijakan Pengelolaan Sampah Daerah Dalam Meningkatkan Kualitas Lingkungan Dan Partisipasi Masyarakat Kreinova

2. Mengetahui dan memahami mengenai Peraturan daerah yang dilaksanakan di masing-masing daerah sehubungan dengan pengelolaan dan pengolahan sampah.

3. Memahami mengenai system pengelolaan sampah bagi masyarakat serta jenis program yang dilaksanakan dari Pemerintah daerah.

Pemerintah kota Depok dalam menjalankan UU No 18 tahun 2008 tentang persampahan, terus ditindak lanjutai dengan berbagai macam Peraturan Daerah yang berkaitan dengan Persampahan, perda-perda tersebut antaran lain:

1. Peraturan Daerah Kota Depok Nomor O5 Tahun 2014 Tentang Pengelolaan sampah

2. Peraturan Daerah Kota Depok Nomor 03 Tahun 2013 Tentang
Pedoman Erlindungan Dan Pengelolaan Lingkungan Hidup

3. Peraturan Daerah Kota Depok Nomor 05 Tahun 2012 Tentang Retribusi Pelayanan Persampahan/Kebersihan

4. Peraturan Daerah (Perda) Nomor 16 Tahun 2012 Tentang Larangan Membuang Sampah Sembarangan.

5. Perda No 5/2014 tentang Retribusi Pelayanan.

6. Peraturan Daerah Kota Depok No 5 Tahun 2014 Tentang Retribusi Pelayanan Resmi Berlaku Sejak 1 Januari 2015.

Kota Depok dengan Jumlah penduduk sudah mencapai 2.179.810, sedangkan di 2015 sebanyak 2.106.100. dengan begitu selama setahun sedikitnya 73.710 penduduk bertambah di Depok. Semakin bertambah jumlah penduduk maka kota Depok mengalami polemik khususnya dalam pembuangan sampah dikarenakan lahan TPA semakin sedikit, ditengah perkembangan masyarakat semakin cepat sebagai kota setelit, terutama dengan perkembangan cepat area perumahan, maka semakin sulit untuk membuat TPA baru, sedangkan TPA Cipayung sudah tidak memuat sampah dari masyarakat dalam jumlah yang banyak. Pemerintah Kota Depok sudah menggagas pendirian Unit Pengolahan Sampah (UPS) sejak tahun 2006 sebelum Undang-undang tengan sampah di umumkan. Fungsi dari UPS adalah diwajibkan ke masyarakat agar sampah yang diangkut ke Tempat Pembuatan Akhir (TPA) Cipanyung tinggal sisa atau residu.

Untuk menekan volume sampah yang masuk ke TPA Cipayung, Dinas Lingkungan Hidup dan Kebersihan (DLHK) Kota Depok terus memaksimalkan keberadaan 483 bank sampah di Kota Depok. Selain itu, Unit Pengolahan Sampah (UPS) juga terus dimaksimalkan agar volume sampah bisa berkurang, Pengelolaan bank sampah sampai saat ini baru ada ada 483 bank 
sampah yang beroperasi di 11 kecamatan. Jumlah ini diharapkan bisa terus bertambah, seiring gencarnya sosialisasi pada warga Kota Depok. Untuk bank sampah yang aktif, saat ini baru mampu menampung 1-2 ton sampah warga Depok per hari. Sedangkan, total produksi sampah di kota ini mencapai 1.200 ton per hari.Sampah yang masuk ke TPA Cipayung bisa mencapai $700-750$ ton perhari, sedangkan kapasitas TPA Cipayung sudah overload sejak tahun yang lalu akan tetapi masih dipaksakan untuk menerima sampah warga.

Perencanaan jangka panjang sampai 2020 pemerintah kota Depok menargetkan akan membentuk 895 bank sampah, sehingga dengan penambahan ini, volume sampah yang dibuang ke TPA CIpayung bisa dikurangn secara sifnifikan. Sedangkan tahun ini targetnya diharapkan bisa tercapai 600 bank sampah. Selain bank sampah pemerintah kota Depok juga mempunyai 30 UPS yang aktif. UPS tersebut mempunyai kapasitas untuk menampung 2-2,5 ton sampah per hari. Sehingga warga Depok bisa memilah sampah sebelum dibuang agar beban produksi sampah bisa berkurang. Keikutsertaan masyarakat dapat dilihat dari respon masyarakat terhadap pembentukan bank sampah animonya sangat besar. Antusias warga terlihat sangat tinggi, baik untuk pembentukan bank sampah maupun kegiatan pemilahan sampah., bahkan saat ini masyrakat sudah aktif membentuk kelompok-kelompok di bidang pengelolaan sampah.

Keuntungan didirkannya bank sampah bisa membuat masyarakat semakin semangat dan serius untuk mengolah bank sampah diwilayahnya, karena mendapatkan keuntungan ekonomis serta mengurangi volume sampah. Sehingga kegiatan ini patut mendapat dukungan dari RT / RW dilingkungan masyarakat tersebut. Karena selain mendapat keuntungan lingkungan menjadi bersih, ada sisi finansialnya seperti misalnya dari hasil penjualan sampah an organic, bisa menjadi kas RT/ RW didaerahnya sehingga para warga tidak lagi dipungut iurananya, sehingga dana bisa dialokasikan untuk kegiatan kemasyarakat dai RT/RW masing-masing. Melalui Perda tersebut Pemerintah Kota Depok mempunyai serta menggalakan antara lain terus menggalakan program-program baru untuk masyarakat khususnya dalam pemilihan sampah yang melibatkan masyarakat.

Ada beberapa program yang dicanangkan antara lain:

1. Meluncurkan gerakan Partai Ember disetiap kelurahan, yang merupakan wujud dan tekad bersama warga Depok untuk melakukan pemilahan sampah dari sumbernya yaitu dari rumah masing-masing warga, perkantoran ataupun tempat hiburan. Gerakan partai ember ini merupakan singkatan dari Ekonomis, Mudah dan bersih

2. Pengolahan sampah dilakukan dengan cara pemilahan antara sampah organic dan an organic di setiap rumah, sehingga kalua sudah terpilih dan terpilah akan dikumpulkan dalam ember kecil pada setiap rumah. Proses selanjutkan akan dibawa dan dikumpulkan di ember yang lebih besar lagi yang ditempatkan ditengah-tengah antara $20-30$ rumah dalam satu RT, selanjutnya sampah yang terkumpul dalam ember besar akan diambil kemudian diangkut oleh Tim dari Dinas Kebersihan (sudah ada petugasnya yang ditentukan).

3. Tahap selanjutnya dari sampahsampah yang diambil oleh petugas dari DKP akan diolah di Unit Pengolahan Sampah (UPS) untuk dijadikan Kompos, sehingga hasilnya akan dinikmati oleh masyarakat/ masyarakat dapat mengambil hasil sampah organic tadi. 
4. Untuk sampah an organiknya akan disalurkan ke bank sampah masing-masing untuk dioleh dan hasilnya bisa memberikan keuntungan dan manfaat secara ekonomis bagi masyarakat

5. Dalam memasyarakatkan partai ember ini, pemerintah daerah menunjuk artis/ tokoh masyarakat sebagai Duta Partai Ember. Sehingga Proses sosialisasi akan sampai ke Masyarakat. Karena dengan diangkatnya artis atau tokoh masyarakat, membuat masyarakat senang dan ingat kalua yang memberikan sosialisasi artis atau tokoh terkenal di masyarakat.

6. Gerakan mengolah sampah dengan cara ini mampu berguna menyadarkan masyarakat terutama masyarakat yang tinggal di bantaran sungai/kali, untuk lebih disiplin dalam menjaga kebersihan, sehingga masyarakat tidak tergantung kepada pengangkatan sampah yang dilakukan oleh pemerintah, dan dengan cara seperti ini bisa menyelesaikan masalah sampah dari pusat produksi sampah, yaitu masyarakat sendiri. Karena kesadaran dari masyarakat dan keinginan dari diri sendiri untuk mengolah dan mengelola sampah yang dibuangnya sendiri, itu yang dibutuhkan dari keberhasilan program Partai Ember ini.

7. Pemerintah Kota Depok menyadari bahwa mengubah kebiasaan masyarakat tidak semudah membalikkan telapak tangan

Partai Ember ini adalah simbol paten bahwa program pilih, pilah sampah dengan teknik ember adalah buah pemikiran dari Kota Depok. Sampai tahun 2016 pemerintah Kota Depok sudah melaksanakan sosialisasi 500 kali, akan tetapi dalam hal ini DKP belum melihat perubahan yang signifikan sehingga perlu ditambah lagi sosialisasi pada tahun 2017 ini sehingga mencapai 600 kali akan disebarkan di seluruh kecamatan kota Depok. Untuk tahun 2017 pemerintah kota Depok menganggarkan Rp. 200 juta, digunakan untuk menyediakan emberembar sebagai wadah untuk sampahsampah organic dan an organic yang akan menampung 25 keluarga dengan ember ukuran kecil. Selain program partai ember juga, tetap program Bank Sampah dilakukan sosialisasi terrus menerus khususnya untuk mengolah sampah an organic, karena Program Bank sampah sendiri memiliki metode pilah, pilih sampah rumah tanggan yang nantinya masyaakat atau setiap warga iktu memilah sampah khususnya sampah an organic pada ember besar. Sehingga akan mengurangi jumlah sampah yang akan diangkut ke TPA Cipayung. Penamaan Parti Ember adalah untuk mudah diingat masyarakat, meskipun tidak ada hubungannya dengan partai politik yang ada ditengah masyarakat, setidaknya partai ember ini membuat masyarakat merasa menolong dan menguntungkan secara ekonomi. Pemda Kota Depok berharap, dengan adanya program ini akan memberikan kesadaran kepada masyarakat untuk bergerak bersama mewujudkan Kota Depok yang bersih, nyaman, dan sehat.

Peraturan Daerah (Perda) Nomor 16 Tahun 2012 tentang Laangan membuang Sampah Sembarangan sudah dilaksanakan dengan baik di Kota Depok. Tujuan diadakannya Perda ini karena dilate belakangi setelah banyaknya lahan tidur di Kota Depok yang dimanfaatkan warga untuk membuang sampah. Dan warga juga dilarang membuang sampah di selokan,kali atau sungai yang bisa mengakibatkan banjir. Adapun sanksi yang dikenakan bagi warga yang membuang sampah sembarangan bisa terancam denda hingga Rp 50 juta. Apabila masih mengulangi perbuatannya itu, sanksi akan diberlakukan dan mereka tidak boleh complain karena sebelumnya sudah menandatangani surat perjanjian. Pelaksanaan Sanksi terhadap pembuang 
sampah di Kota Depok sudah di laksanakan oleh Dinas kebersihan dan pertamanan kota Depok dengan mengambil tindakan tegas dalam mengukum dan mengadili 150 dari 244 orang yang melakukan membuang sampah sembarangan.

Pemberlakukan hukumannya dalah dengan hukuman tindak pidana ringan denda atau kurungan 3 bulan penjara. (kusumo . 2016) . adapun cara penegakkan hokum dilakukan dengan mengerahkan Tim buser sampah untuk menangkap warga yang melakukan membuang sampah, ternyata dari separuh warga yang membuang sampah sembarangan bukan warga Depok.

Perintah Kota Depok mulai Tahun 2016 mencabut retribusi sampah bagi masyarakat. , karena merupakan konsekuensi diterapkannya Perda No 5/2014 tentang Retribusi Pelayanan. Pencabutan retibusi sampah ini pun berimbas hilangnya pendapatan asli daerah (PAD) sebesar Rp3 milair dari retribusi sampah. Alasan lain dengan dihapuskannya restribusi sampah itu disebabkan banyak oknum yang mengaku petugas DKP menarik iuran sampah. Program- program yang diluncurkan oleh pemerintah kota Depok, khususnya yang berkaitan dengan program pengelolaan dan pengolahan sampah, selalu di sertai perubahan-perubahan pada aturan-aturan yang dilaksanakan untuk masyarakat. Anrara lain Peraturan Daerah Kota Depok No 5 Tahun 2014 tentang Retribusi Pelayanan resmi berlaku sejak 1 Januari 2015. Tujuan dengan di keluarkannya Perda Kota Depok No 5 tahun 2014 adalah warga perumahan dibebaskan dari pembayaran iuran sampah. Dan ini sudah resmi berlaku sejak tahun 2015. Adapun tujuan dari diberlakukannya perda ini tentang penghapusan retribusi sampah:

1. Mendorong masyarakat untuk wajib memilah sampahnya masingmasing menjadi 3 bagian.

2. Mendorong Rukun Tetangga dan Rukun Warga untuk menciptakan pengurus khusus pengelolaan sampah.

3. RT/RW bisa menggunakan anggaran atau biaya yang biasanya dibayarkan ke Dinas Kebersihan untuk membiayai operasional pengurus pengolahan sampah di wilayahnya.

Sampah yang terpilah akan dibawa oleh petugas Dinas Kebersihan dan Pertamanan ke beberapa tempat berbeda sesuai dengan jenisnya. Yaitu Sampah jenis organik akan dipisah dan ditempatkan di dalam ember oleh masyarakat untuk kemudian diambil secara berkala petugas kebersihan. sampah organik ini akan dibawa oleh petugas kebersihan menuju Unit Pengelolaan Sampah setempat.Sampah jenis non-organik akan dikumpulkan di bank sampah masing-masing RT/RW untuk dikelola dan dimanfaatkan. Residu sampah kedua jenis organik dan nonorganik akan dibawa oleh petugas Dinas Kebersihan dan Pertamanan ke tempat Pembuangan Sampah Akhir.

\section{KESIMPULAN DAN SARAN}

Kota Depok dengan diterbitkannya Perda Nomor : Peraturan Daerah Kota Depok Nomor O5 Tahun 2014 Tentang Pengelolaan sampah , Peraturan Daerah Kota Depok Nomor 03 Tahun 2013 Tentang Pedoman Erlindungan Dan Pengelolaan Lingkungan Hidup, Peraturan Daerah Kota Depok Nomor 05 Tahun 2012 Tentang Retribusi Pelayanan Persampahan/Kebersihan, Peraturan Daerah (Perda) Nomor 16 Tahun 2012 Tentang Larangan Membuang Sampah Sembarangan, Perda No 5/2014 tentang Retribusi Pelayanan, Peraturan Daerah Kota Depok No 5 Tahun 2014 Tentang Retribusi Pelayanan Resmi Berlaku Sejak 1 Januari 2015.

Hambatan yang menyebabkan pengelolaan serta pengolahan sampah di kabupaten maupun kota kurang berjalan sesuai dengan program, yaitu: 
1. Belum meratanya sosialisasi peraturan kepada masyarakat

2. Masyarakat belum peduli terhadap program-program yang dilaksanakan

3. Setelah sosialisasi, masyarakat lupa lagi

4. Terkendala dengan dana/ modal untuk pengadaan peralatan, karena belum semua masyarakat mendapatkan dari pemerintah daerah.

\section{UCAPAN TERIMA KASIH}

Ucapan terima kasih kepada :

1. P3M Politeknik Negeri Jakarta

2. Pemda Depok dalam hal ini Dinas Lingkungan Hidup dan Kebersihan

3. Pimpikan IKDU Indonesia Hijau

\section{DAFTAR PUSTAKA}

Badan perencanaan Pembangunan Nasional 2010. Buku Potensi Ekonomi

Enviromental Service Program (ESP)

DKI. 2006. Modul Pelatihan Pengelolaan Sampah Ber-basis Masyarakat.

Faizah. 2008. Pengelolaan Sampah Rumah Tangga Berbasis Masyarakat (Studi Kasus di Kota Yogyakarta). Tesis Magister Ilmu Ling-kungan. Universitas Diponegoro. Semarang

Komang Ayu, Ni. 2009. Peran Serta Masyarakat dalam Pengelolaan Sampah Rumah Tang-ga (Studi Kasus di Sampangan dan Jomblang, Kota Semarang). Tesis Magister Ilmu Lingkungan. Universitas Diponegoro. Semarang.
Purdiyanto. 2009. Peran Serta Masyarakat dalam penanganan Sampah untuk Meningkatkan Mutu Lingkungan. Laporan Penelitian Ke-sehatan Lingkungan dan Kerja.

Surbakti, Sriliani. 2009. Potensi Pengelolaan .Sampah Menuju Zero Waste yang Berbasis Masyarakat di Kecamatan Kedungkandang Kota Malang. Laporan Penelitian Institut Teknologi Surabaya.

Salim, Emil. 23 Juni, 2005. Hidup Dari Sampah, Belajar dari Prof Hasan Poerbo.Harian Kompas.

http://hasanpoerbo.blogspot.com/2006/0 4/hi dup-dari-sampah-belajar-dariprof.html [14 Maret 2010].

Najmudin Ramli. 2007. Pariwisata berwawasan lingkungan. Jakarta

Scheyvens, R., \& Mornsen, J. H. (2008). Tourism and poverty reduction: issues for small island states. Tourism Geographies, 10(1), 22e41.

Yoeti Oka. 1996. Pengantar ilmu Pariwisata. Bandung : Penerbit Angkasa

\section{Jurnal :}

Latianingsih,nining. 2010. Implementasi hokum bisnis melalui kegiatan koperasi sampah dalam rangka pemberdayaan masyarakat. Jurnal Ekonomi Bisnis PNJ.

Jurnal triwulan Pembangunan Daerah No.02 tahun 2006

Umar, Ibnu. 2009. Pengelolaan Sampah Secara Terpadu di Wilayah Perkotaan. Jurnal Ling-kungan Hidup.

M. Jaafar, S.A. Maideen. School of Housing Building and Planning, Universiti Sains Malaysia, Minden, 11800 Georgetown, Penang, Malaysia / Tourism Management 33 (2012) 683e691 journal homepage: www.elsevier.com/locate/tourman 
Medlik, S., \& Middleton, V. T. C. (1973).

Product formulation in tourism. In.

Tourism and marketing, Vol. 13.

Berne: AISET.

Anonim, 2008. Olah Sampah,

http://www.pus dakota, Jakarta 
